\title{
Germination Response of Ornamental Pine Seeds on a Two-Way Thermogradient Plate
}

\author{
Marcos Vieira Ferraz ${ }^{*}$, Kathia Fernandes Lopes Pivetta ${ }^{1}$, Hugh W. Pritchard ${ }^{2}$, \\ Tim Marks², Marcelo Vieira Ferraz ${ }^{3}$, Leandro José Grava de Godoy ${ }^{3}$ \\ ${ }^{1}$ Department of Plant Production, São Paulo State University (Unesp), Jaboticabal, Brazil \\ ${ }^{2}$ The Millenium Seed Bank, Royal Botanic Kew Gardens, Ardingly, England \\ ${ }^{3}$ Campus of Registro, São Paulo State University (Unesp), Registro, Brazil \\ Email: *ferrazmarcos@yahoo.com.br
}

How to cite this paper: Ferraz, M.V., Pivetta, K.F.L., Pritchard, H.W., Marks, T., Ferraz, M.V. and de Godoy, L.J.G. (2018) Germination Response of Ornamental Pine Seeds on a Two-Way Thermogradient Plate. American Journal of Plant Sciences, 9, 13-22.

https://doi.org/10.4236/ajps.2018.91002

Received: November 1, 2017

Accepted: January 7, 2018

Published: January 10, 2018

Copyright (c) 2018 by authors and Scientific Research Publishing Inc. This work is licensed under the Creative Commons Attribution International License (CC BY 4.0).

http://creativecommons.org/licenses/by/4.0/

(c) (i) Open Access

\begin{abstract}
The objective of this study was to evaluate the effect of temperature on germination of Pinus tabuliformis Carrière seed, Pinus gerardiana Wall. ex D. Don and Pinus roxburghii Sarg. Seeds of three species were distributed in Petri dishes with $1 \%$ agar solution; for the first step it was placed on a 2-way Grant's thermogradient plate (a bi-directional incubator) for a period of 28 days and during the second step in an incubator type B.O.D. also for 28 days with non-germinated seeds in the first step. This instrument allows an assessment of a wide regime of constant and alternating temperatures, resulting to 144 different combinations of temperature, scheduled to the temperatures $4^{\circ} \mathrm{C}-40^{\circ} \mathrm{C}$. The lighting regime was 12 hours photoperiod for the two stages of the experiment. The best temperature for the germination of $P$. tabuliformis was $26.2^{\circ} \mathrm{C}$ (minimum of $7.9^{\circ} \mathrm{C}$ and maximum $37.0^{\circ} \mathrm{C}$ ) and $P$. roxburghii was $15.6^{\circ} \mathrm{C}$ (minimum $10,4^{\circ} \mathrm{C}$ and maximum $37.0^{\circ} \mathrm{C}$ ). The seeds are neutral photoblastic. P. gerardiana showed low germination percentage (below 10\%). The temperature that provided the highest germination percentage for $P$. tabuliformis was $26.2^{\circ} \mathrm{C}$ and $15.6^{\circ} \mathrm{C}$ for P. roxburghii.
\end{abstract}

\section{Keywords}

Thermogradient Plate, Temperature Regime, Germination Percentage

\section{Introduction}

The study of temperature and light, suitable for the germination of forest species, has received attention in the scientific and academic environment, in order to use such information either for germination, for its conservation in seed 
banks for the production of plants in nurseries, for recovery of degraded areas and for landscaping.

For germination, it is necessary that some intrinsic factors of the seed and related environmental act favorably. To this end, it is essential that the seed is alive, there is no numbness and has availability of water, temperature and oxygen [1].

Each species requires specific conditions for germination to happen, especially the quality of the presence of light and proper temperature [2]. These two environmental factors are of fundamental importance in controlling germination, and are considered to be the main extrinsic factors that influence germination [3] [4] [5].

Carvalho and Nakagawa [5] and Souza et al. [6] report that the effect of temperature on the germination can be described in terms of cardinal temperatures (minimum, optimum and maximum). The minimum and maximum temperatures are those in which, respectively above and below the seed does not germinate and the optimum temperatures for maximum germination percentage in the shortest period of time.

The effect of the presence of light favors somehow germination for some species, designating this effect as positive photoblastic. For other species the effect of the absence of light is considered better that the presence of light and this effect is called as the negative effect photoblastic. When they are indifferent to light this effect is called neutral photoblastism [7] [8] [9].

The thermogradient plate is a bi-directional incubator [10], and it permits for germination testing of seeds over a wide range of single temperature and alternating temperature regimes over a time continuum [11].

Pinaceae family species are among the most valuable and commercially important plants in the world. Most species are trees, and often are excellent sources of wood, wood products and resins; many are grown for reforestation and as ornamentals [12].

The pine, called matsu by the Japanese, is considered the "king" of plants in a garden and it is believed that this plant brings good fortune. In the floral art of ikebana, its branches and leaves are used in floral arrangements as a symbol of good luck [13].

In landscaping, many species of pine are used, such as Pinus densiflora, Pinus parviflora, Pinus pentaphylla, Pinus pumila, Pinus thunbergii [14].

Among the species of pine trees with high potential for landscaping, the main focus of this work are: Pinus gerardiana, Pinus roxburghii and Pinus tabuliformis.

P. tabuliformis, also known as Chinese pine, is an important ecologically and economically, a kind of native tree conifer in northern China, which naturally is distributed in 14 provinces and municipal regions, with a land cover about 3 million $\cdot \mathrm{km}^{2}[15]$.

Also known as Himalayan pine, $P$. roxburghii, is a native tree species in the 
Midwest of the Himalayas, which is a third of the area of the Uttarakhand Himalaya Forest, between Siwaliks and Himalayan rivers, from Kashmir to Bhutan [16].

$P$. gerardiana is a species that grows in Pakistan, Afghanistan and India. This produces fruit species, called pinions, which are rich sources of unsaturated fatty acids and which, when ripe, has a good adhesive property anionic polysaccharide [17].

Although they have ornamental and industrial importance, there is still little information on literature on seed germination of these species. This work aimed to evaluate the effect of temperature on germination of Pinus tabulaeformis, Pinus gerardiana and Pinus roxburghii seeds.

\section{Material and Methods}

The work was carried out in the laboratories of the Millennium Seed Bank (MSB), Kew Gardens, Ardingly, England, with pine seeds ( $P$. tabuliformis, $P$. gerardiana and $P$. roxburghii), acquired from a commercial company.

In the germination test, the seeds were rinsed in sodium hypochlorite at $2 \%$ for 10 minutes under gentle manual mixing. Then, the seeds were washed three times in distilled water. Only after this disinfecting process is that then the seeds were distributed in Petri dishes (5 $\mathrm{cm}$ diameter) with $1 \%$ agar solution.

To analyze the effects of temperature alternating light was used 12 hours photoperiod (light with a photon flux of $50-100 \mathrm{~W} / \mathrm{m}$ ) and alternating temperatures (day/night), which gave rise to a line of constant temperature from the bottom left of thermogradient table (always cold) to the upper right corner (always hot), as shown above (Figure 1 ).

The factorial scheme was $12 \times 12$ petri plates, which generated a diagonal line from the lower left corner to the upper right corner (bold) with alternating temperature fluctuations of 12 hours in one direction during the day and 12 hours in another direction at night, with temperatures from 4 to 40 degrees Celsius.

Two temperature gradients were programmed into the thermogradient plate

\begin{tabular}{|c|c|c|c|c|c|c|c|c|c|c|c|}
\hline \multicolumn{12}{|c|}{ Hot / Day } \\
\hline $35.1 / 6.6$ & $35.3 / 9.4$ & $35.5 / 12.1$ & $35.6 / 14.9$ & $35.8 / 17.6$ & $36.0 / 20.4$ & $36.2 / 23.1$ & $36.4 / 25.9$ & $36.6 / 28.6$ & $36.7 / 31.4$ & $36.9 / 34.1$ & 37.0 \\
\hline $32.7 / 6.7$ & $32.8 / 9.4$ & $33.0 / 12.2$ & $33.2 / 14.9$ & $33.3 / 17.7$ & $33.5 / 20.4$ & $33.7 / 23.2$ & $33.8 / 25.9$ & $34.0 / 28.7$ & $34.2 / 31.4$ & 34.3 & $34.5 / 36.8$ \\
\hline $30.3 / 6.7$ & $30.4 / 9.5$ & $30.5 / 12.2$ & $30.7 / 15.0$ & \begin{tabular}{|l|}
$30.9 / 17.7$ \\
\end{tabular} & \begin{tabular}{|l|}
$31.0 / 20.5$ \\
\end{tabular} & $31.2 / 23.2$ & $31.3 / 26.0$ & $31.5 / 28.7$ & \begin{tabular}{|l|}
31.6 \\
\end{tabular} & $31.8 / 34.3$ & $31.9 / 36.7$ \\
\hline $27.8 / 6.8$ & $28.0 / 9.5$ & $28.1 / 12.3$ & $28.2 / 15.0$ & $28.4 / 17.8$ & $28.5 / 20.5$ & $28.7 / 23.3$ & 28. $8 / 26.0$ & 28.9 & $29.1 / 31.6$ & $29.2 / 34.3$ & $29.3 / 36.7$ \\
\hline $25.4 / 6.8$ & $25.5 / 9.6$ & $25.7 / 12.3$ & $25.8 / 15.1$ & $25.9 / 17.8$ & $26.0 / 20.6$ & $26.1 / 23.3$ & 26.2 & $26.4 / 28.9$ & $26.5 / 31.6$ & $26.6 / 34.4$ & $26.7 / 36.6$ \\
\hline $23.0 / 6.9$ & $23.1 / 9.6$ & $23.2 / 12.4$ & $23.3 / 15.1$ & $23.4 / 17.9$ & $23.5 / 20.6$ & 23.5 & $23.7 / 26.2$ & $23.8 / 28.9$ & $23.9 / 31.7$ & $24.0 / 34.4$ & $24.1 / 36.5$ \\
\hline $20.6 / 6.9$ & $20.7 / 9.7$ & $20.8 / 12.4$ & $20.9 / 15.2$ & $20.9 / 17.9$ & 20.9 & $21.1 / 23.5$ & $21.2 / 26.2$ & $21.3 / 29.0$ & $21.4 / 31.7$ & $21.5 / 34.5$ & $21.6 / 36.4$ \\
\hline $18.2 / 7.0$ & $18.2 / 9.7$ & $18.3 / 12.5$ & $18.4 / 15.2$ & 18.2 & $18.5 / 20.8$ & $18.6 / 23.5$ & $18.7 / 26.3$ & $18.7 / 29.0$ & $18.8 / 31.8$ & $18.9 / 34.5$ & $19.0 / 36.3$ \\
\hline $15.8 / 7.0$ & $15.8 / 9.8$ & $15.9 / 12.5$ & 15.6 & $16.0 / 18.1$ & \begin{tabular}{|l|}
$16.0 / 20.8$ \\
\end{tabular} & $16.1 / 23.6$ & $16.1 / 26.3$ & $16.2 / 29.1$ & $16.3 / 31.8$ & $16.3 / 34.6$ & $16.4 / 36.2$ \\
\hline $13.3 / 7.1$ & $13.4 / 9.8$ & 13.0 & $13.5 / 15.4$ & \begin{tabular}{|l|}
$13.5 / 18.1$ \\
\end{tabular} & \begin{tabular}{|l|}
$13.5 / 20.9$ \\
\end{tabular} & $13.6 / 23.6$ & $13.6 / 26.4$ & $13.7 / 29.1$ & $13.7 / 31.9$ & $13.7 / 34.6$ & $13.8 / 36.2$ \\
\hline $10.9 / 7.1$ & 10.4 & $11.0 / 12.7$ & $11.0 / 15.4$ & $11.0 / 18.2$ & $11.0 / 20.9$ & $11.1 / 23.7$ & $11.1 / 26.4$ & $11.1 / 29.2$ & $11.1 / 31.9$ & $11.2 / 34.7$ & $11.2 / 36.1$ \\
\hline 7.9 & $8.5 / 10.0$ & $8.5 / 12.7$ & $8.5 / 15.5$ & \begin{tabular}{|l|}
$8.5 / 18.2$ \\
\end{tabular} & $8.5 / 21.0$ & $8.6 / 23.7$ & $8.6 / 26.5$ & $8.6 / 29.2$ & $8.6 / 32.0$ & $8.6 / 34.7$ & $8.6 / 36.0$ \\
\hline
\end{tabular}

Figure 1. Distribution of temperatures in the thermogradient plate used to evaluate germination responses of $P$. gerardiana; $P$. roxburghii and $P$. tabuliformis. 
in such a way as to vary from $4{ }^{\circ} \mathrm{C}$ to $40^{\circ} \mathrm{C}$. The first programmed temperature gradient started from bottom to top and, after 12 hours, alternated with another gradient from left to right.

This scheme allowed for 144 temperature regimes, of which 12 were constant and 132 were of alternating regimes.

The seeds were examined daily, and only when the radicle was two millimeters or more in length were considered in the evaluation.

The experiment was conducted for 28 days in the two-way thermogradient plate and, in addition to this step, the non-germinated seeds were conditioned in a germination chamber type $\mathrm{BOD}$, regulated at a temperature of $25^{\circ} \mathrm{C} \pm 1.0^{\circ} \mathrm{C}$ and photoperiod of 12 hours, to evaluate the viability of germination of the same.

The length, width and weight of 25 seeds were calculated. Each seed was evaluated individually for the determination of these measures.

To determine the length and width, a Zeiss Axiocam scale ruler coupled to a microscope (Zeiss Stemi SV11) was used. The data are presented as means, with their respective standard errors.

To determine the humidity, a portable digital hygrometer was used. The method measures the relative humidity balance, i.e. the relative humidity of the air in equilibrium with the seeds held in a closed chamber. It is fast, and non-destructive, making it ideal for small collections of rare and/or endangered species [18].

For the graphical presentation of the germination percentage, the SigmaPLot computer program was used.

\section{Results and Discussion}

The $P$. gerardiana species, probably due to the low seed quality, presented low germination (below 10\%) for some temperature regimes at the thermogradiente plate and, therefore, was not evaluated for this experiment.

A large variation in length, width and weight was observed for the seeds of $P$. tabuliformis, $P$. gerardiana and $P$. roxburghii. For the species $P$. tabuliformis an average of $7.48 \pm 0.92 \mathrm{~mm}$ for the length was found, $4.31 \pm 0.51 \mathrm{~mm}$ for the width and $0.04 \pm 0.01 \mathrm{mg}$ for the weight. For $P$. roxburghii, the mean was $9.63 \pm$ $1.11 \mathrm{~mm}$ for the length, $5.27 \pm 0.61 \mathrm{~mm}$ for the width and $0.05 \pm 0.02 \mathrm{mg}$ for the weight.

The arrangement of the species in the plate of thermogradiente allowed 144 possible combinations, being 48 combinations for each of the three species. Germination occurred in 43 combinations for P. tabuliformis, 27 for $P$. roxburghii and 7 for $P$. gerardiana.

The germination rates, in percentage, and the seed distribution scheme in the thermogradient plate, during the initial 28 days are shown above (Figure 2).

The highest germination rates for $P$. tabuliformis occurred at the following temperature regimes: $8.6^{\circ} \mathrm{C} / 23.7^{\circ} \mathrm{C}(100 \%) ; 11.1^{\circ} \mathrm{C} / 26.4^{\circ} \mathrm{C}(100 \%) ; 16.1^{\circ} \mathrm{C} /$ 


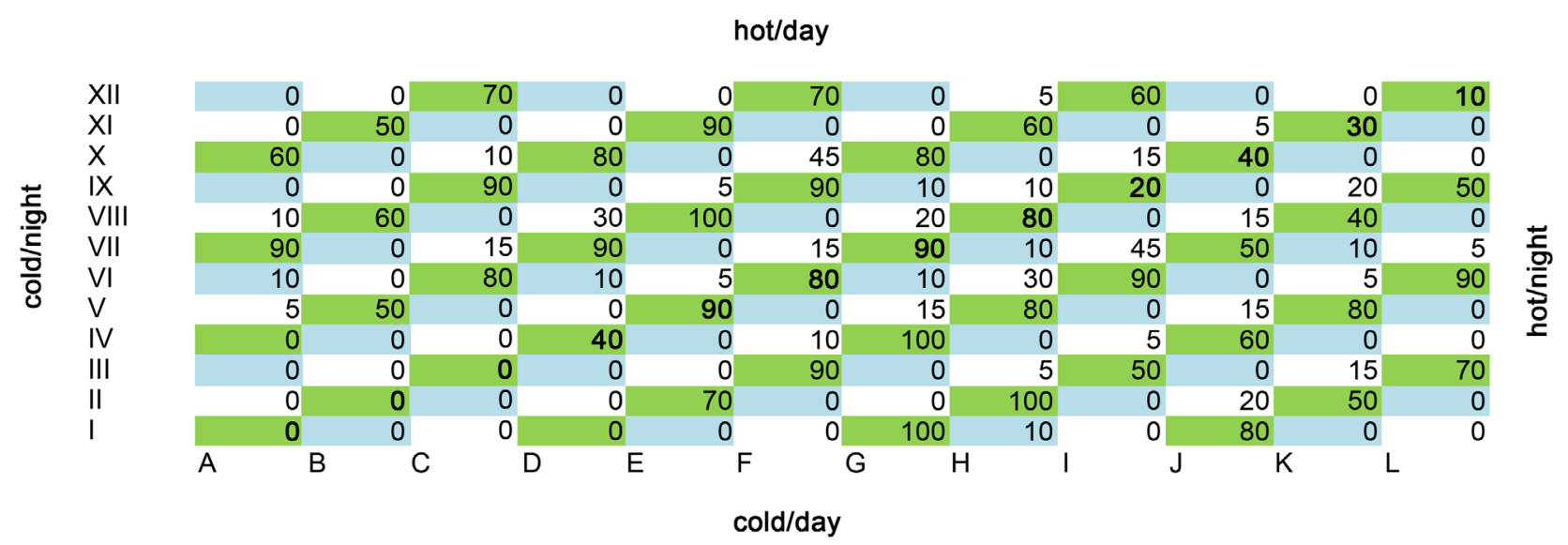

Figure 2. Scheme of distribution of the species and their germination points in the thermogradient plate used to evaluate germination responses of Pinus gerardiana (blue cells); Pinus roxburghii (white cells) and Pinus tabuliformis (green cells).

$23.6^{\circ} \mathrm{C}(100 \%) ; 25.9^{\circ} \mathrm{C} / 17.8^{\circ} \mathrm{C}(100 \%) ; 13.5^{\circ} \mathrm{C} / 20.9^{\circ} \mathrm{C}(90 \%) ; 18.2^{\circ} \mathrm{C}(90 \%)$; $21.3^{\circ} \mathrm{C} / 29.0^{\circ} \mathrm{C}(90 \%) ; 21.6 / 36.4(90 \%) ; 23.0^{\circ} \mathrm{C} / 6.9^{\circ} \mathrm{C}(90 \%) ; 23.3^{\circ} \mathrm{C} / 15.1^{\circ} \mathrm{C}$ (90\%); $23.5^{\circ} \mathrm{C}(90 \%) ; 28.1^{\circ} \mathrm{C} / 12.3^{\circ} \mathrm{C}(90 \%)$. P. roxburghii were: $23.8^{\circ} \mathrm{C} / 28.9^{\circ} \mathrm{C}$ $(45 \%) ; 31.0^{\circ} \mathrm{C} / 20.5^{\circ} \mathrm{C}(45 \%) ; 21.2^{\circ} \mathrm{C} / 26.2^{\circ} \mathrm{C}(30 \%)$ and $25.8 / 15.1(30 \%)$.

It is noted that the seeds arranged in the low temperature regimes, ie the seeds that were placed near the lower left corner, with temperatures close to $7.9^{\circ} \mathrm{C}$ did not germinate. The same observation occurs for the seeds placed near the upper right corner, that is, near the temperature of $37^{\circ} \mathrm{C}$, with no or low germination.

The same was observed for seeds of Khayaanthotheca, Meliaceae family, when submitted from $5^{\circ} \mathrm{C}$ to $40^{\circ} \mathrm{C}$ in a thermogradient dish with $100 \%$ germination at $5^{\circ} \mathrm{C} / 30^{\circ} \mathrm{C}$ (day/night) and zero germination in regimes close to extreme temperatures [19].

The best constant temperature for germination of Terminalia superba, Combretaceae family, is $35^{\circ} \mathrm{C} / 35^{\circ} \mathrm{C}$ and the best temperature combinations at alternating temperatures were $35^{\circ} \mathrm{C} / 40^{\circ} \mathrm{C}\left(100 \%\right.$ germination), $35^{\circ} \mathrm{C} / 15^{\circ} \mathrm{C}$ (95\%), $40^{\circ} \mathrm{C} / 25^{\circ} \mathrm{C}(95 \%), 20^{\circ} \mathrm{C} / 40^{\circ} \mathrm{C}$ and $40^{\circ} \mathrm{C} / 30^{\circ} \mathrm{C}$ (92.5\%) [20].

The optimal temperature zone for germination of cotton seed was determined to be $28^{\circ} \mathrm{C}$ to $30^{\circ} \mathrm{C}$. As temperature decreased from the optimal zone, the germination rate decreased but percentage germination during the 10 -day period was significantly lower only below $20^{\circ} \mathrm{C}$. As the temperature increased above the optimal zone, the germination rate decreased and the percentage germination sharply decreased above $32^{\circ} \mathrm{C}-34^{\circ} \mathrm{C}[21]$.

Seed germination of Moringaoleifera and $M$. peregrine, Moringaceae family, in laboratory showed that $20^{\circ} \mathrm{C}$ is the optimum temperature degree for both species. Good germination was also recorded at $15^{\circ} \mathrm{C}$ and $25^{\circ} \mathrm{C}$ for $M$. oleiferaand $M$. peregrina, respectively. Nogermination was obtained from any speciesunder $10^{\circ} \mathrm{C}$ and $40^{\circ} \mathrm{C}$ [22].

It is observed, when comparing the germination above and below the constant temperature line, that is, when in the presence of light at low temperatures al- 
ternating with the presence of light at high temperatures, that there was no influence of light in the germination process for the Species studied.

The period for the first germination was affected due to the temperature regime. For $P$. tabuliformis the time for the first germination was three days, under the temperature regime of $36.6^{\circ} \mathrm{C} / 28.6^{\circ} \mathrm{C}$, and for $P$. roxburghii, it was five days in the regime of $29.2^{\circ} \mathrm{C} / 34.3^{\circ} \mathrm{C}$.

The germination rate or germination speed, expressed as $1 / \mathrm{T} 50$, which is the time in days to reach $50 \%$ of the final germination percentage, was affected by the temperature regimes at which the seeds were arranged for germination in the dish of two-way thermogradient.

The results found for the germination speed were estimated for the constant temperature line of $7.9^{\circ} \mathrm{C}$ to $37.0^{\circ} \mathrm{C}$. This model allowed the calculation of the cardinal temperatures (minimum, optimum and maximum), presented graphically as a line of descent and descent of temperatures, where the intersection of the straight lines represents the optimal temperature for the germination of each species.

According to these models, the best temperature for the germination of $P$. tabuliformis was $26.2^{\circ} \mathrm{C}$ (minimum of $7.9^{\circ} \mathrm{C}$ and maximum of $37.0^{\circ} \mathrm{C}$ ) and for $P$. roxburghii it was $15.6^{\circ} \mathrm{C}$ (minimum of $10.4^{\circ} \mathrm{C}$ and maximum of $37.0^{\circ} \mathrm{C}$ ).

The results of the germination, in percentage, obtained from the thermogradient plate, can also be shown in other types of graphs, where it is observed that the lower right (always cold) and upper right (always hot) corners exhibit low or no germination. (Figure 3 for $P$. tabuliformis, and Figure 4 for $P$. roxburghii).

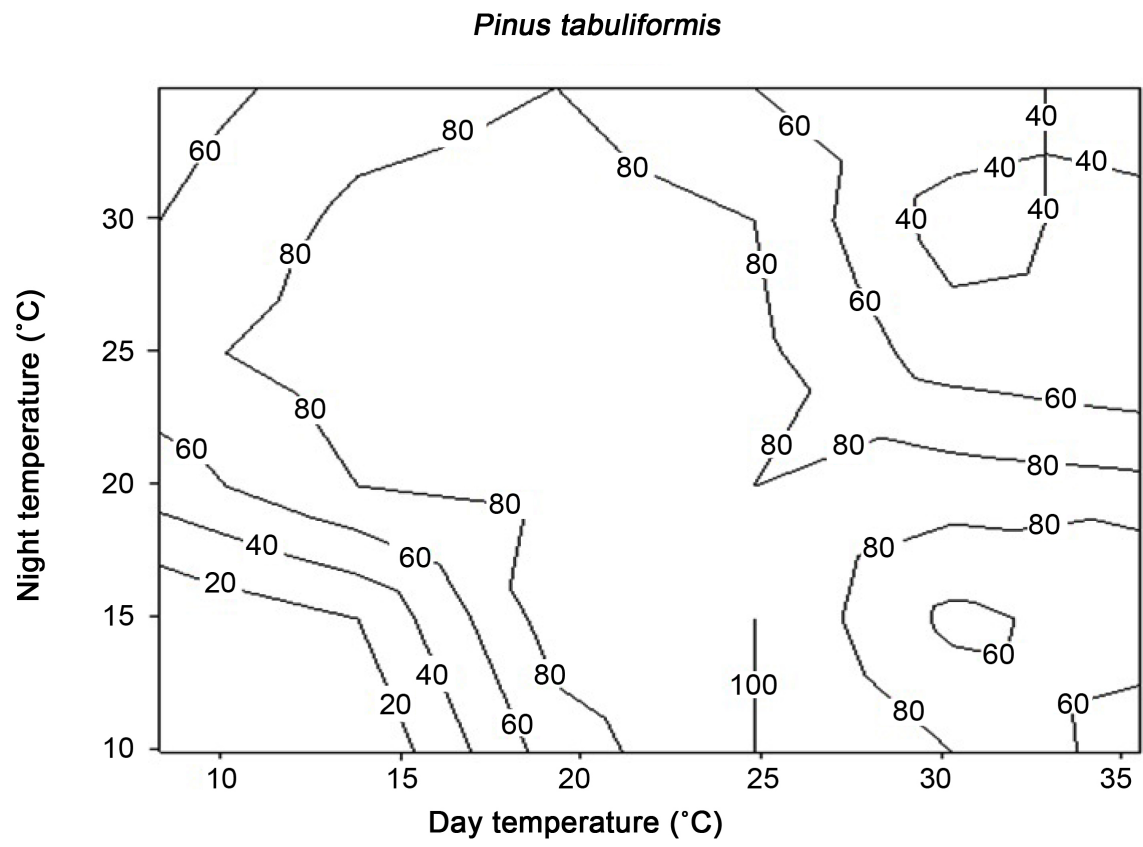

Figure 3. Percentage of germination of Pinus tabuliformis in two-way thermogradient plate in 12 hours of photoperiod. The numbers represent the percentage of germination and the curves show the limits between the results obtained. 


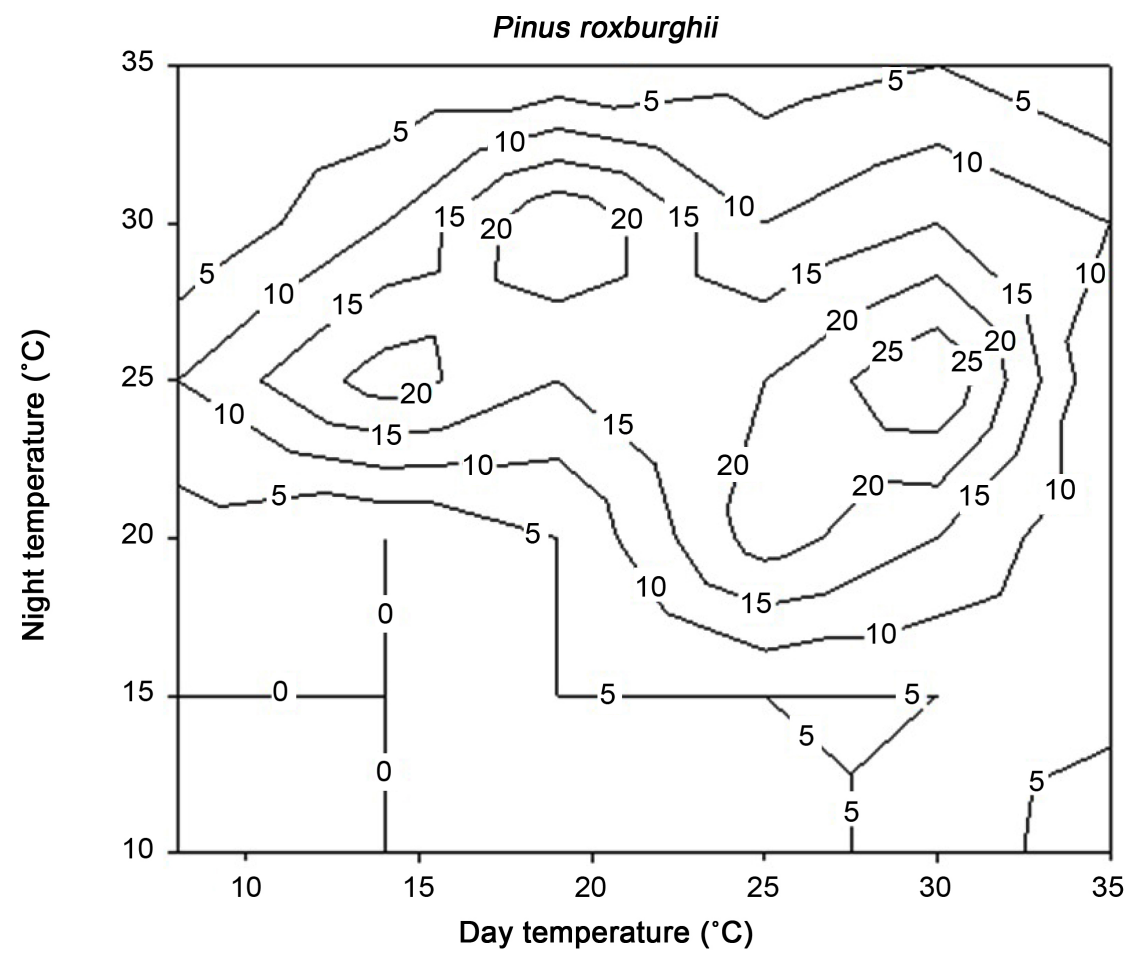

Figure 4. Percentage of germination of Pinus roxburghii in two-way thermogradient plate in 12 hours of photoperiod. The numbers represent the percentage of germination and the curves show the limits between the results obtained.

After incubation for 28 days in thermogradient plate, the non-germinated seeds were placed in incubator type B.O.D. At $25^{\circ} \mathrm{C}$ for a further 28 days. The results are shown above (Figure 5 ).

The germination values obtained in this second stage of the study show that the seeds under extreme temperatures were not dead.

For P. tabuliformis, it is observed that the seeds that were under low or high temperature in the first stage of the experiment, in a plate of thermogradiente, when placed under a temperature of $25^{\circ} \mathrm{C}$ (temperature close to the ideal of germination, which was $26.2^{\circ} \mathrm{C}$ ), germinated. In the temperature regime of $10.4^{\circ} \mathrm{C}$ there was no germination and under temperature of $25^{\circ} \mathrm{C}$ it presented $100 \%$ of germination. In the $37^{\circ} \mathrm{C}$ regime, where there was $10 \%$ germination, under a temperature of $25^{\circ} \mathrm{C}$ it presented $80 \%$ germination.

For $P$. roxburghii the same effect was observed and $40 \%$ germination was observed in a B.O.D. type incubator at $25^{\circ} \mathrm{C}$, where there had previously been no germination at the thermogradient table for the $11.0^{\circ} \mathrm{C} / 15.4^{\circ} \mathrm{C}$ regime (day/ night).

This is consistent with what Borges and Rena [23] and Bewley and Black [24] reported that in the viable seed at rest, by quiescence or dormancy, when they have met a number of exogenous and endogenous conditions, that is, extrinsic and intrinsic factors, there will be reactivation of the metabolism and, consequently, the growth of the embryo, which will lead to germination. 
hot/day

\begin{tabular}{|c|c|c|c|c|c|c|c|c|c|c|c|c|}
\hline \multirow{13}{*}{$\begin{array}{l}\text { XII } \\
\text { XI } \\
\text { X } \\
\text { IX } \\
\text { VIII } \\
\text { VII } \\
\text { VI } \\
\text { V } \\
\text { IV }\end{array}$} & 0 & 0 & 10 & 0 & 0 & 10 & 0 & 5 & 30 & 0 & 5 & 60 \\
\hline & 5 & 20 & 0 & 0 & 0 & 0 & 5 & 30 & 10 & 15 & 20 & 10 \\
\hline & 0 & 0 & 25 & 0 & 0 & 10 & 0 & 0 & 0 & 40 & 0 & 0 \\
\hline & 0 & 15 & 10 & 0 & 10 & 0 & 0 & 15 & 40 & 0 & 15 & 30 \\
\hline & 25 & 0 & 0 & 40 & 0 & 0 & 10 & 0 & 0 & 0 & 50 & 0 \\
\hline & 0 & 0 & 5 & 0 & 10 & 15 & 0 & 0 & 10 & 20 & 0 & 0 \\
\hline & 0 & 35 & 0 & 0 & 20 & 10 & 0 & 0 & 0 & 0 & 25 & 0 \\
\hline & 20 & 40 & 0 & 30 & 0 & 0 & 5 & 0 & 0 & 25 & 0 & 0 \\
\hline & 70 & 0 & 20 & 40 & 0 & 20 & 0 & 0 & 10 & 0 & 0 & 0 \\
\hline & 0 & 35 & 90 & 0 & 25 & 0 & 0 & 10 & 0 & 0 & 10 & 30 \\
\hline & 30 & 100 & 0 & 40 & 30 & 0 & 10 & 0 & 0 & 0 & 10 & 0 \\
\hline & 60 & 0 & 15 & 90 & 0 & 25 & 0 & 0 & 15 & 10 & 0 & 10 \\
\hline & A & $B$ & C & D & $F$ & & G & $\mathrm{H}$ & & $\mathrm{J}$ & $\mathrm{K}$ & \\
\hline
\end{tabular}

Figure 5. Germination, in percentage, of Pinus gerardiana (cells in blue color); Pinus roxburghii (white cells) and Pinus tabuliformis (cells in green color), during the second stage of the experiment, in incubator type B.O.D.

\section{Conclusion}

The optimum temperature for germination for Pinus tabuliformis is $26.2^{\circ} \mathrm{C}$ and for Pinus roxburghii is $15.6^{\circ} \mathrm{C}$.

\section{Acknowledgements}

Coordination for the Improvement of Higher Level Personnel (Coordenação de Aperfeiçoamento de Pessoal de Nível Superior-Capes).

\section{References}

[1] Novembre, A.D.daL.C., Faria, T.C., Pinto, D.H.V. and Chamma, H.M.C.P. (2007) Teste de germinação de sementes de sansão-do-campo (Mimosa caesalpiniaefolia Benth.-Fabaceae-Mimosoideae). Revista Brasileira de Sementes, Brasília, 29, 47-51. https://doi.org/10.1590/S0101-31222007000300006

[2] Copeland, L.O. and Mcdonald, M.B. (1999) Principles of Seed Science and Technology. Kluwer Academic Publishers, London, 409 p.

https://doi.org/10.1007/978-1-4615-1783-2

[3] Andrade, A.C.S. (1995) Efeitos da luz e da temperatura na germinação de Leandra breviflora Cong., Tibouchina benthamiana Cong. Tibouchina grandiflora Cong. e Tibouchina moricandia (DC) Baill. (Melatomataceae). Revista Brasileira de Sementes, Brasília, 17, 29-35. https://doi.org/10.17801/0101-3122/rbs.v17n1p29-35

[4] Santos Neto, A.L.D., Filho, S.M., Teófilo, E.M., Guimarães, R.M., Blank, A.F. and Silva-Mann, R. (2008) Influência da Luz e da temperatura na germinação de sementes de sambacaitá (Hyptis pectinata (L.) Poit). Revista Brasileira de Agrociência, Pelotas, 14, 19-26.

[5] Carvalho, N.M. and Nakagawa, J. (2000) Sementes: Ciência, tecnologia e produção. 4th Edition, FUNEP, Jaboticabal, 151-159.

[6] Sousa, M.P., Braga, L.F., Braga, J.F. and Delachiave, M.E.A. (2008) Germinação de sementes de Plantago ovata Forsk. (Plantaginaceae): Temperatura e fotoblastismo. Revista Árvore, Viçosa, 32, 51-57. https://doi.org/10.1590/S0100-67622008000100007

[7] Labouriau, L.G. (1983) A germinação das sementes. Secretaria Geral da OEA, 
Washington, $173 \mathrm{p}$.

[8] Mayer, A.M. and Poljakoff-Mayber, A. (1989) The Germination of Seeds. Pergamon, Oxford, $270 \mathrm{p}$.

[9] Silva, L.M.M., Rodrigues, T.J.D. and Aguiar, E.B. (2002) Efeito da luz e a temperatura na germinação de sementes de aroeira (Myracrodruon urundeuva). Revista Árvore, Viçosa, 26, 691-697.

[10] Manger, K.R. (1999) Use of Grant Thermogradient Plate. Millenium Seed Bank, Kew.

[11] Tarasoff, C.S., Louhaichi, M., Mallory-Smith, C. and Ball, D.A. (2005) Using Geographical Information Systems to Present Nongeographical Data: An Example Using 2-Way Thermogradient Plate Data. Rangeland Ecology \& Management, 58, 215-218. https://doi.org/10.2111/04-112R.1

[12] Fu, L., Li, N., Elias, T.S. and Mill, R.R. (2012) Pinaceae. Flora of China, 4, 11.

[13] Sawano, T. (2008) Creating Your Own Japanese Garden. Japan Publications Trading, Tokyo, $120 \mathrm{p}$.

[14] Levy-Yamamori, R. and Taaffe, G. (2004) Garden Plants of Japan. Timber Press, Portland, $440 \mathrm{p}$.

[15] Li, W., Wang, X. and Li, Y. Stability in and Correlation between Factors Influencing Genetic Quality of Seed Lots in Seed Orchard of Pinus tabuliformis Carr. over a 12-Year Span. Plos One, 6, 1-9.

[16] Ghildiyal, S.K., Sharma, C.M. and Khanduri, V.P. (2007) Improvement in Germination of Chirpine (Pinus roxburghii) by a Presowing Treatment with Hydrogen Peroxide. Journal of Tropical Forest Science, 19, 113-118.

[17] Haq, M.A., Alam, M.J. and Hasnain, A. (2012) Gum Cordia: A Novel Edible Coating to Increase the Shelf Life of Chilgoza (Pinusgerardiana). LWT-Food Science and Technology, London.

http://ac.els-cdn.com/S0023643812002253/1-s2.0-S0023643812002253-main.pdf?_ti $\mathrm{d}=\mathrm{fc} 2489 \mathrm{a} 0096859 \mathrm{f} 7 \mathrm{a} 4 \mathrm{f} 2 \mathrm{ce} 8 \mathrm{~b} 14697777$ \&acdnat $=1345593247 \_335 \mathrm{a} 833 \mathrm{bb} 39 \mathrm{eaf8e00a}$ ce19f1ca869f5

[18] Measuring Seed Moisture Status Using a Hygrometer. http://www.kew.org/sites/default/files/assets/PPCONT_014346_Primary.pdf

[19] Asomaning, J.M., Sacande, M. and Olympio, N.S. (2010) Germination Responses of Khayaanthotheca Seeds to Range of Alternating and Constant Temperature Provided by the 2-Way Grant's Thermogradient Plate. Ghana Journal of Forestry, 26, 74-78.

[20] Asomaning, J.M., Sacande, M. and Olympio, N.S. (2011) Germination Responses of Terminalia superb Engl. and Diel Seeds on the 2-Way Grant's Thermogradient Plate. Research Journal of Seeds Science, 4, 28-39.

https://doi.org/10.3923/rjss.2011.28.39

[21] Krzyzanowski, F.C. and Delouche, J.C. (2011) Germination of Cotton Seed in Relation to Temperature. Revista Brasileira de Sementes, 33, 543-548. http://www.scielo.br/scielo.php?script=sci_arttext\&pid=S0101-31222011000300017 \&lng=en\&nrm=iso https://doi.org/10.1590/S0101-31222011000300017

[22] Hassanein, A.M.A. and Al-Soqeer, A.A. (2017) Evaluation of Seed Germination and Growth Characteristics of Moringaoleifera and $M$. peregrinaunder Laboratory, Greenhouse, and Field Conditions. International Journal of Agriculture and Biolo$g y, 19,873-879$. 
[23] Borges, E.E.I. and Rena, A.B. (1993) Germinação de sementes. In: Aguiar, I.B., Pinã-Rodrigues, F.C.M. and Figliolia, M.B., Eds., Sementes Florestais Tropicais, ABRATES, Brasília, 83-136.

[24] Bewley, J.D. and Black, M. (1994) Seeds: Physiology of Development and Germination. Plenum Press, New York, 445 p. https://doi.org/10.1007/978-1-4899-1002-8 